Journal of Contemporary Research in Business, Economics and Finance

ISSN: 2641-0265

Vol. 2, No. 3, pp. 61-70

2020

Publisher: Learning Gate

DOI: 10.33094/26410265.2020.23.61.70

(C) 2020 by the authors; licensee Learning Gate

\title{
How Attribute-Based Design Perceptions and Consumer-Brand Relationship Affected on Brand Equity?
}

\author{
Abdolhossein Karampour \\ Assistant Professor of Economy and Management, Shiraz University, Iran. \\ Email: a_karampour2004@yahoo.com \\ Bahareh Ahmadinejad \\ Department of Management, Islamic Azad University (IAU), Qazvin Branch, Qazvin, Iran. \\ Email: bahare_ahmadi1365@yahoo.com
}

Received: 1 September 2020; Revised: 5 October 2020; Accepted: 16 October 2020; Published: 26 October 2020

\begin{abstract}
Consumers act differently in choosing brands. Some like certain brands but some do not. A major reason is the design of products made by brands and the quality of experience. In general, companies can differentiate their products from competitors by focusing on physical features such as taste, design, and non-physical features such as price, brand, and country of origin. this research investigates design perception including (five design perceptual dimensions, namely visual, functional, kinesthetic, interface and information) and its effects on brand equity and experience. User expertise was considered as a mediating variable. Partial least squares path modeling (PLS) was used to test the research model. Samples were randomly collected from GLX smartphone phone consumers, and 367 samples included in this research. The reliability and validity of the questionnaire were evaluated using Cronbach's alph a coefficient, combined reliability, divergent validity and confirmatory analysis. The results showed an acceptable reliability and validity. Pearson correlation coefficient and PLS software were used to analyze the data. The outcomes showed that design perception positively and significantly affects the experimental value and brand equity and experimental value positively affect brand equity. Finally, moderating user expertise's vivacious and significant role in the relationship between design perception and the experimental value confirmed.
\end{abstract}

Keywords: Design perception, Experimental value, Brand equity, Brand awareness, User expertise, Brand associations.

\section{Introduction}

Today's, successful organizations have a common goal. They care about the customers and are seriously committed to marketing and have a high sense of commitment in recognizing the needs of customers, satisfying customers and understand their target market as well (Kotler, Keller, Ancarani, \& Costabile, 2014).

One of the most critical issues which organizations address is brand equity. Farquhar (1989) stated brand value increases the value of products (brand, symbol, logo) (Farquhar, 1989). Brand equity is a set of assets and liabilities associated with a brand that increases or decreases the value created by a product or service for a company and their customers (Aaker, 1996).

Brand equity is an essential concept in marketing, management, and branding as higher brand equity caused higher cash flows and increased competitiveness (Marques, da Silva, Davcik, \& Faria, 2020). Researchers examined brand value from two different perspectives: first from a financial perspective and a buyer perspective second from a financial perspective and a company's assets (Keller, 1993; Severi \& Ling, 2013). 
These studies will emphasize buyers' perspectives or perceptions of brand archiving. Brand value from the buyers' perspective include customer behavior (Farquhar, 1989) and customer perception (Mahajan, Alloul, Collin, \& Marucco, 1994).

Prasad and Dev (2000) suggested brand evaluation affect from the brand awareness, brand image associations, service quality. Besides, Aaker (1996); Aaker (1992) suggests that the combination of perceived value, brand perceptions, and firm credibility are fruitful in the brand quality assessment process (Aaker, 1992; Aaker, 1996). Brand equity has many benefits for companies and manufacturers e.g., if brands have a high equity value, customers will have a positive attitude towards the brand which lead them to pay a high price for the product, repeat their purchase and word-of-mouth advertising (Mishra, 2016).

Therefore, to increase the positive partnership and manage brand assets, companies need to develop strategies that increase brand equity (Keller, 2007). Improving the benefits of the product/service and reducing costs make increase the value of products/services, significant competitive advantage, profitability and customer satisfaction (Choi, Cho, Lee, Lee, \& Kim, 2004).

Customer value defined as the customer's assessment of the costs and benefits of purchasing a product/service (Teas \& Agarwal, 2000; Zeithaml, 1988). Lin., Sher, and Shih (2005) believed customer value is essential for any organization (Lin et al., 2005). Therefore, companies' primary goals should focus on the continuous improvement of customer experience values and mechanisms that increase the value of customer experience (Bagdare \& Jain, 2013; Payne, Holt, \& Frow, 2000). The customer experience is a set of interactions between the customer, product, and a company or organization that increases these interactions and shows these personal experiences and customer activities at different levels, evaluating which depends on comparing customer expectations and motivations. The definition covers the communication, physical, effectiveness, cognitive, and sensory parts (Bagdare \& Jain, 2013) which the company presents and combines different moments of interaction with tangible points.

Thus, customer experience is essential key to improve customer relationship_brand and brand equity due to providing economic value to companies (Brakus, Schmitt, \& Zarantonello, 2009; Frow \& Payne, 2007). Most of the times, customer satisfaction, brand loyalty and brand equity are outcomes of customer experience (Fornell \& Larcker, 1981; Lee \& Back, 2010; Mishra, 2016; Wang, Siu, \& Hui, 2004; Zhang, Jiang, Shabbir, \& Du, 2015). Generally, identifying the factors that affect the experimental value and brand equity are vital to every industry.

\subsection{Design Perception}

Product design is the overall output of all production processes within an organization, acting as the first interface between the product, the brand, and the user (Luchs \& Swan, 2011). A well-designed product creates a set of concepts and experiences as well (Hekkert \& Leder, 2008). Design features act as leverage so that a design team can create a product. In addition, the product strives to achieve design goals that include a superior presentation to the user to generate perfect brands (Noble \& Kumar, 2010). Besides, the customer compares the product based on its brand equity features and experiential value (Keller, 1993). GLX phones are a good choice for those who care about design of their phone, but this phone is a good choice not only in appearance but also in terms of hardware specifications and is worth buying (Figure 1 is an example of a GLX G6).

Journal of Contemporary Research in Business, Economics and Finance
ISSN: 2641-0265
Vol. 2, No. 3, pp. $61-70,2020$
DOI: $10.33094 / 26410265.2020 .23 .61 .70$
C) 2020 by the authors; licensee Learning Gate




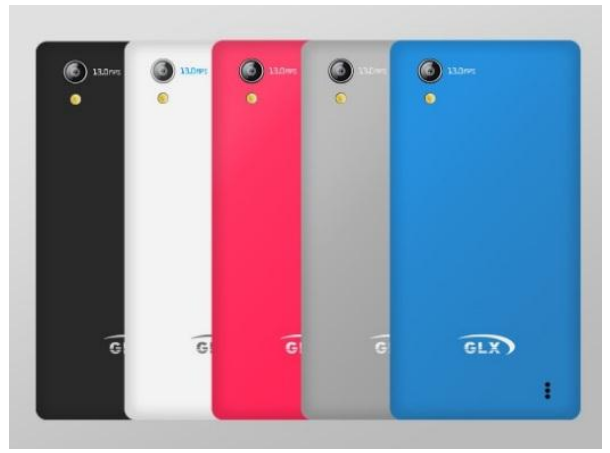

Figure-1.

GLX G6 phone design.

H1: Design perception (visual, functional, kinesthetic, interface and information) affects the experiential value (usability, social value, and enjoyment).

\subsection{Experimental value}

The consumer experience derives its meaning from the broader concept of consumer value which related to the direct or indirect (remote) products/service experiences (Hansen \& Christensen, 2003). According to Halbork's typology, three values determine user experience: usability, social value, and enjoyment of use. Nelson (1994) defines product applicability by using efficiency, learning ability, maintenance, error, satisfaction, ease of use and usefulness (Kumar \& Noble, 2016).

Through innovative designs, products depict the credibility of individuals and their personalities and contribute to the social status (Jung, Kim, \& Lee, 2014). Produce new products is a motivation for social identity and psychological benefits (Petruzzellis \& Somma, 2010). Direct experience is the knowledge gained after consuming a product which is build attitudes about products/brands based on information about the product. Schudson (1984) explains that direct experience plays the most prominent role in a brand's consumer choice. For example, even if a person collects information about a game, they will not accurately evaluate that game unless they play that game. Since the 1960 s, many concepts have been developed about the customer experience, but everyone agrees that the customer experience should include interaction with people, processes, or the organization's system. Some said that experience includes interaction with the product (Schudson, 1984).

In contrast, others said that product experience includes emotions or emotional reactions. Approximately 50\% scholars agree this definition: "Customer experience is a set of all customer interactions with products", for example, all interactions with products, services, and people are affiliated with the company. The customer experience encompasses all points where the customer encounters the organization, product, or service (Kiska, 2002).

H2: Experimental value (usability, social value and pleasure in use) effects on brand equity.

\subsection{Brand Equity}

The American Marketing Association defines a brand as "a name, word, design, symbol, or anything else that distinguishes a seller's product or service from other vendors" (Johansson, 2007). Brand equity in the Aaker model consists of five dimensions: brand awareness, perceived quality, brand image association, brand preference, and other brand property, such as royalties, brands and channel relationships (Aaker, 1992). In 2000, Yoo, Donthu, and Lee (2000) developed the model proposed by Aaker. They showed that brand equity could be created, protected and even developed by strengthening its dimensions.

In subsequent studies by Yoo et al. (2000) a new brand equity model created to integrate brand awareness and image association and consider a dimension (Yoo et al., 2000). A three-dimensional image was created, consisting of brand awareness / image association, perceived quality, and brand preference. 
Based on the customer-oriented Keller and Aaker's conceptual framework of brand equity, brand equity dimensions are sources of value creation for the company and customers (Davcik, da Silva, \& Hair, 2015).

For decades, a company's value was measured in terms of property, then tangible assets, factories, and equipment. Nevertheless, today, the core capital of many businesses is their brand. Brand owners recently concluded that a company's real value is somewhere outside of it, in potential customers (Sharma, Davcik, $\&$ Pillai, 2016). Many scholars have commented on the dimensions of brand equity, which is briefly stated in Table 1.

Table-1.

Sources of brand equity.

\begin{tabular}{|c|c|c|c|c|}
\hline Farquhar (1989) & Doyle (1990) & Aaker (1992) & Keller (1993) & $\begin{array}{l}\text { Kapferer } \\
(1994)\end{array}$ \\
\hline $\begin{array}{l}\text { Elements for } \\
\text { creating a strong } \\
\text { brand } \\
\text { - } \quad \text { Positive } \\
\text { Brand Evaluations } \\
\text { - Accessible } \\
\text { Brand Attitudes } \\
\text { - Consistent } \\
\text { Brand Image }\end{array}$ & $\begin{array}{l}\text { - Quality } \\
\text { - Superior } \\
\text { service } \\
\text { - Innovation } \\
\text { - } \\
\text { Differentiation }\end{array}$ & $\begin{array}{l}\text { Brand Equity } \\
\text { Dimensions } \\
\text { - Brand Loyalty } \\
\text { - Brand Awareness } \\
\text { - Perceived Quality } \\
\text { - Brand Associations } \\
\text { - Other Proprietary } \\
\text { brand assets } \\
\text { - Patents } \\
\text { - Trademarks } \\
\text { - Channel } \\
\text { - relationships }\end{array}$ & $\begin{array}{c}\text { Brand Knowledge } \\
\text { • Brand Awareness } \\
\text { - } \text { Brand Recall } \\
\text { - Brand } \\
\text { Becognition } \\
\text { - } \text { Typd Image } \\
\text { Trand of } \\
\text { Association } \\
\text { - Favorability } \\
\text { of } \\
\text { Brand } \\
\text { Associations } \\
\text { - Strength of } \\
\text { Brand } \\
\text { Associations } \\
\text { Uniqueness } \\
\text { of Brand } \\
\text { Associations }\end{array}$ & $\begin{array}{l}\text { Brand Assets } \\
\text { - Brand } \\
\text { Awareness } \\
\text { - Brand } \\
\text { Reputation } \\
\text { - Perceived } \\
\text { Brand } \\
\text { Personality } \\
\text { - Perceived } \\
\text { Brand Values } \\
\text { - Reflected } \\
\text { Customer } \\
\text { Imagery } \\
\text { - Brand } \\
\text { Preference or } \\
\text { attachment } \\
\text { - Patents and } \\
\text { rights }\end{array}$ \\
\hline
\end{tabular}

Perceived quality is considered one of the most important predictors of brand equity and provides reasons for customers to differentiate the brand from competitors (Pappu \& Quester, 2016). Research also shows a positive relationship between perceived quality and brand associated with brand equity (Buil, De Chernatony, \& Martínez, 2013).

Previous research showed that customer loyalty is one of the main determinants of brand equity (Atilgan, Aksoy, \& Akinci, 2005; Buil et al., 2013; Yoo et al., 2000).

H3: experimental value (usability, social value and pleasure in use) effect on brand equity.

H4: User expertise in the relationship between design perception and experimental value has a moderating role.

\subsection{Brand Associations}

Brand association is agent of brand equity and is defined as terms that include behaviors or characteristics accepted by consumer perception (Aaker, 1992; Keller, 1993). Anything related to a brand in our memory refers to a brand association (Aaker \& Biel, 1993). Brands and logos association can be seen in all forms and reflects the characteristics of a product or aspects of it (Chin, Marcolin, \& Newsted, 2003). The importance of brand association is in gaining advantages that distinguish a particular brand from other brands (Kasper, Strepp, \& Terblanche, 2005). 
Brand association effects on purchase decisions, customer loyalty and brand value. While brand association comes from many sources, brand characteristics and constructive brand association are two of the most crucial brand associations, which effect on brand equity (Aaker, 1996).

\section{Methodology}

This research was conducted on 367 GLX smartphone consumers. To measure the variables, Mishra (2016); Sweeney and Soutar (2001); Yoo et al. (2000) and Mitchell and Dacin (1996) questionnaires were used (Mishra, 2016; Mitchell \& Dacin, 1996; Sweeney \& Soutar, 2001; Yoo et al., 2000). The scoring of the questionnaire questions was based on five-point Likert-type scales (1=strongly disagree and $5=$ strongly agree). SPSS and SMART PLS software was used to analyze data. To check the normality of the data, Kolmogorov-Smirnov test used and indicated data distribution was not normal. Therefore, due to the non-normalization of the research data, structural equation modeling with SMART PLS software was used.

The sample consisted of 289 males and 78 females. Findings show that people with a bachelor's degree $(43.87 \%)$ formed the largest statistical sample size, and most respondents were between the ages of 41 and $50(40.5 \%)$.

To evaluate the reliability of structures, Fornell and Larcker (1981) suggest three criteria, which include: 1- Reliability of each item, 2- Combined reliability of each structure, and 3- Average Variance Extracted. Regarding each item's reliability, the factor load of $0 \leq 0.5$ is defined acceptable structure indicator (Gefen \& Straub, 2005). The Dillon-Goldstein coefficient (c $\rho$ ) was used to evaluate each structure's combined reliability, and acceptable values of c $\rho$ should be $0 \leq 0.7$. Unlike multiple ordinary least squares regression, PLS uses factors load scores for analysis; it is necessary to consider each item's factor load in calculating the reliability index. However, the Cronbach's alpha coefficient gives equal weight to items and shows less reliability, so the coefficient c $\rho$ was used (Manuel et al., 2009). Acceptable values of $c \rho$ should be $0 \leq 0.7$. The third indicator of reliability is the mean-variance extracted (Fornell \& Larcker, 1981). Nunnally and Bernstein recommends AVE values $0 \leq 0.5$ (Nunnally \& Bernstein, 1994).

Partial least squares structural equation modeling (PLS-SEM) is used in business research (Sarstedt, Hair, Ringle, Thiele, \& Gudergan, 2016) and we used for the present study.

All the studied structures have AVE above (0.5), and the results of diagnostic validity showed that all structures are well distributed. Also, all of the $\mathrm{c} \rho$ factors are more than (0.7), so consequence reliability confirmed. According to Table 2 AVE, all research variables are more than their correlation with other variables. Therefore, the second criterion for examining the divergent validity of research variables is established. Also, numbers below the correlation matrix's diameter reported to investigate the relationship between the variables. The correlation coefficient between all variables is positive and significant.

\section{Results}

Figure 2 shows the coefficients of the $T$ pathways of the research. T coefficients above $(1.96 \pm 1.02$ to $+2.58)$ are significant at the level of $(0.05)$, and $\mathrm{T}$ coefficients are higher than $( \pm 0.28)$ at the level of (0.01). Also, in Table 2, the estimated path coefficient and variance in the research model reported. 
Table-2.

CFA Results.

\begin{tabular}{|c|c|c|c|c|c|c|}
\hline Variable & Item & Factor load & T Value & AVE & $\mathbf{c \rho}$ & $\alpha$ \\
\hline \multicolumn{7}{|c|}{ CFA Results- Design perception } \\
\hline \multirow{5}{*}{ Visual design } & $\mathrm{TB} 1$ & 0.65 & 16.32 & \multirow{5}{*}{0.54} & \multirow{5}{*}{0.85} & \multirow{5}{*}{0.78} \\
\hline & $\mathrm{TB} 2$ & 0.74 & 26.28 & & & \\
\hline & TB3 & 0.69 & 16.34 & & & \\
\hline & $\mathrm{TB} 4$ & 0.8 & 38.21 & & & \\
\hline & TB5 & 0.74 & 33.78 & & & \\
\hline \multirow{7}{*}{ Functional design } & TK 1 & 0.78 & 37.29 & \multirow{7}{*}{0.52} & \multirow{7}{*}{0.88} & \multirow{7}{*}{0.85} \\
\hline & TK2 & 0.8 & 38.85 & & & \\
\hline & TK3 & 0.81 & 39.62 & & & \\
\hline & TK4 & 0.74 & 29.20 & & & \\
\hline & TK5 & 0.65 & 17.56 & & & \\
\hline & TK6 & 0.65 & 18.92 & & & \\
\hline & TK7 & 0.6 & 12.75 & & & \\
\hline \multirow{3}{*}{ Kinesthetic design } & TH1 & 0.81 & 37.74 & \multirow{3}{*}{0.69} & \multirow{3}{*}{0.87} & \multirow{3}{*}{0.77} \\
\hline & $\mathrm{TH} 2$ & 0.85 & 57.41 & & & \\
\hline & TH3 & 0.82 & 42.69 & & & \\
\hline \multirow{5}{*}{ Interface design - user } & $\mathrm{TR} 1$ & 0.68 & 20.07 & \multirow{5}{*}{0.55} & \multirow{5}{*}{0.86} & \multirow{5}{*}{0.80} \\
\hline & $\mathrm{TR} 2$ & 0.79 & 42.27 & & & \\
\hline & TR3 & 0.74 & 22.44 & & & \\
\hline & $\mathrm{TR} 4$ & 0.75 & 26.48 & & & \\
\hline & TR5 & 0.72 & 23.99 & & & \\
\hline \multirow{5}{*}{ Information design } & TE1 & 0.77 & 29.02 & \multirow{5}{*}{0.62} & \multirow{5}{*}{0.89} & \\
\hline & $\mathrm{TE} 2$ & 0.75 & 32.10 & & & \\
\hline & TE3 & 0.81 & 39.85 & & & 0.84 \\
\hline & TE4 & 0.78 & 35.05 & & & \\
\hline & TE5 & 0.8 & 41.94 & & & \\
\hline CFA results - experime & & & & & & \\
\hline & GS1 & 0.77 & 34.26 & & & \\
\hline & $\mathrm{GS} 2$ & 0.83 & 43.59 & & & \\
\hline & GS3 & 0.79 & 33.73 & & & \\
\hline Ucobility & GS4 & 0.86 & 47.69 & & & \\
\hline Usabillty & GS5 & 0.83 & 45.13 & 0.70 & 0.95 & 0.95 \\
\hline & GS6 & 0.87 & 80.86 & & & \\
\hline & GS7 & 0.88 & 67.16 & & & \\
\hline & GS8 & 0.86 & 65.41 & & & \\
\hline & GS9 & 0.82 & 45.71 & & & \\
\hline & $\mathrm{AE} 1$ & 0.83 & 47.71 & & & \\
\hline Social value & AE2 & 0.83 & 24.02 & & & \\
\hline & AE3 & 0.85 & 60.74 & 0.68 & 0.90 & 0.84 \\
\hline & $\mathrm{AE} 4$ & 0.77 & 29.27 & & & \\
\hline & $\mathrm{LS} 1$ & 0.81 & 36.84 & & & \\
\hline & $\mathrm{LS} 2$ & 0.87 & 51.18 & & & \\
\hline Pleasure in use & LS3 & 0.87 & 66.80 & 0.74 & 0.93 & 0.91 \\
\hline & $\mathrm{LS} 4$ & 0.87 & 66.35 & & & \\
\hline & $\mathrm{LS} 5$ & 0.85 & 53.96 & & & \\
\hline CFA results - brand eq & & & & & & \\
\hline & $\mathrm{AB} 1$ & 0.76 & 28.41 & & & \\
\hline Brand oquity & $\mathrm{AB} 2$ & 0.71 & 22.34 & & & \\
\hline Brand equity & AB3 & 0.88 & 71.31 & 0.64 & 0.88 & 0.81 \\
\hline & $\mathrm{AB} 4$ & 0.83 & 39.06 & & & \\
\hline
\end{tabular}




\begin{tabular}{|c|c|c|c|c|c|c|}
\hline CFA results $-\mathrm{u}$ & & & & & & \\
\hline \multirow{4}{*}{ User expertise } & $\mathrm{T} 1$ & 0.78 & 16.59 & \multirow{4}{*}{0.60} & \multirow{4}{*}{0.86} & \multirow{4}{*}{0.79} \\
\hline & $\mathrm{T} 2$ & 0.70 & 10.46 & & & \\
\hline & T3 & 0.79 & 24.20 & & & \\
\hline & $\mathrm{T} 4$ & 0.81 & 28.88 & & & \\
\hline
\end{tabular}

Table-3.

Discriminant validity (Fornell-Larcker criterion).

\begin{tabular}{l|c|c|c|c}
\hline Variable & $\mathbf{1}$ & $\mathbf{2}$ & $\mathbf{3}$ & $\mathbf{4}$ \\
\hline Design perception & $0.84^{* *}$ & & & \\
\hline Experiential value & $0.68^{* *}$ & 0.89 & & \\
\hline Brand equity & $0.66^{* *}$ & $0.68^{* *}$ & 0.80 & \\
\hline User expertise & 0.37 & $0.31^{* *}$ & $0.23^{* *}$ & 0.77 \\
\hline
\end{tabular}

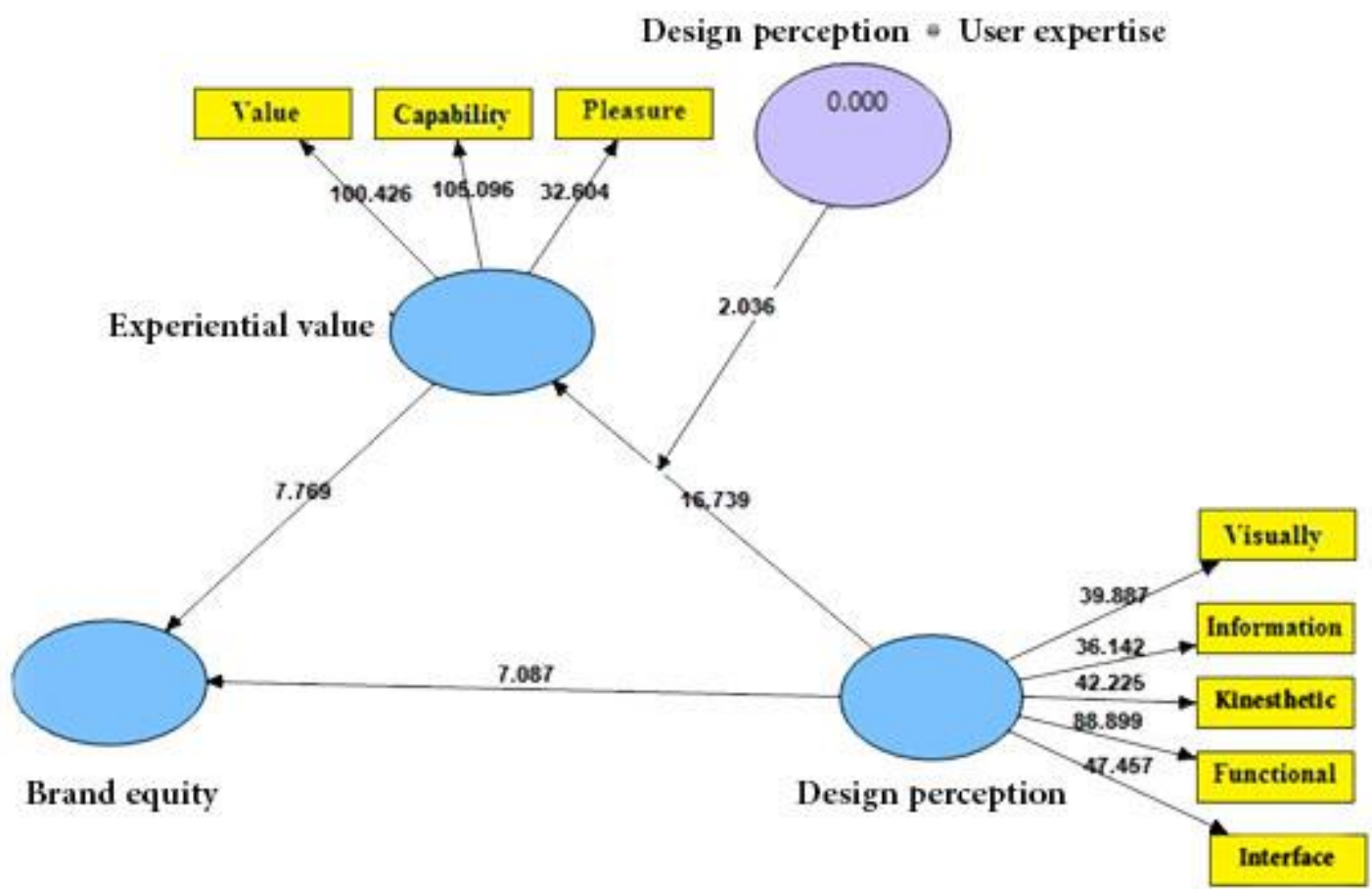

Figure-2.

T-test coefficients of the research.

Table-4.

Path coefficients and variance.

\begin{tabular}{l|c|c}
\hline Variables & Direct coefficients & Variance explained \\
\hline On the brand equity: & $0.37^{* *}$ & 0.53 \\
Design perception & $0.42^{* *}$ & $0.65^{* *}$ \\
Experiential value & 0.50 \\
\hline On the experiential value: design perception & 0 \\
\hline
\end{tabular}

According to Table 4, design perception and experiential value have a positive and significant effect on brand equity. Also, $50 \%$ of the variance in the experiential value and $53 \%$ of the brand equity variance is explained by the research model's variables. 
Table-5.

Indirect coefficients, modulators, and T coefficients.

\begin{tabular}{l|c|c}
\hline Variables & Indirect coefficients & Coefficients t \\
\hline $\begin{array}{l}\text { The indirect effect of design perception on brand equity } \\
\text { through: Experiential value }\end{array}$ & $0.27^{* *}$ & 7.05 \\
\hline $\begin{array}{l}\text { The role of moderating the user's expertise in the } \\
\text { relationship between design perception and brand equity }\end{array}$ & $0.13^{*}$ & 2.04 \\
\hline
\end{tabular}

In Table 5, indirect coefficients, moderator coefficients, and T-model coefficients have been reported. As can be seen, the indirect effect of design perception has a meaningful effect on a brand equity. The e user's expertise in the relationship between design perception and brand equity has a positive moderating role.

Table-6.

CV-Communality and CV-Redundancy.

\begin{tabular}{c|c|c}
\hline Research variables & $\mathbf{Q}^{2}(\mathbf{C V}-\mathbf{R e d u n d a n c y})$ & CV-Communality \\
\hline Design perception & - & 0.715 \\
\hline Experiential value & 0.373 & 0.789 \\
\hline Brand equity & 0.224 & 0.640 \\
\hline User expertise & - & 0.600 \\
\hline
\end{tabular}

Table 6 shows the CV-Redundancy and CV-Communality of the research variables. As shown in the table, all the values of CV-Redundancy and CV-Communality are positive, which indicates the appropriate and acceptable quality of the present research model. Finally, to show the validity of the research model's findings, the fitting indices of structural equation models were used by the partial least squares method. As shown in Table 3, the positive values of CV-Communality and CV-Redundancy for all variables in the present study indicate the appropriate and acceptable quality of the measurement and structural model. In addition to the above indicators, the index of overall model maturity is in the PLS of the GOF index. It can be used to check the validity or quality of the PLS pattern in general. For the tested model, the index of the absolute fitting of GOF was (0.57), that the value for this fit index indicated a suitable fit for the test pattern.

\section{Conclusion}

The results showed that design perception has a positive and significant direct effect on experiential value. Therefore, design perception leads to an increase in the value of experience. The value of experience in brand equity has a direct positive and significant effect. Therefore, the value experience leads to increase brand equity. Design perception and experimental value have a direct positive and significant effect on brand equity. Therefore, this result leads to increase brand equity. Finally, outputs showed moderating user expertise in the relationship between design perception and brand equity is positive and significant. These findings are consistent with the peasant results, Mishra (2016) studies.

This finding suggests that if users are familiar with smartphones, their ideas about smartphone features make them eager. They gain information about smartphones, then compare to other people such as friends and relatives with more information and rise design perception and brand equity.

In general, research has shown that design perception has a positive and significant direct impact on experiential value. Therefore, design perception increases experiential value. Design perception has a direct positive and significant effect on brand equity. Therefore, design perception makes high brand equity. The role of moderating expertise user in the relationship between design perception and experiential value is positive and meaningful. At the end, the user's expertise in the relationship between design perception and experiential value plays a moderating role. 


\section{References}

Aaker, D. A. (1992). Managing brand equity: Capitalizing on the value of a brand. The Journal of Marketing, 56(2), 125-134.

Aaker, D. (1996). Measuring brand equity across products and markets. California Management Review, 38(3), 102-120. Available at: https://doi.org/10.2307/41165845.

Aaker, D. A., \& Biel, A. L. (1993). Brand equity and advertising: An overview. Hillsdale, NJ: Lawrence Erlbaum Associates.

Atilgan, E., Aksoy, S., \& Akinci, S. (2005). Determinants of the brand equity: A verification approach in the beverage industry in Turkey. Marketing Intelligence \& Planning, 23(3), 237-248. Available at: https://doi.org/10.1 108/02634500510597283.

Bagdare, S., \& Jain, R. (2013). Measuring retail customer experience. International Journal of Retail \& Distribution Management, 41(10), 790-804. Available at: https://doi.org/10.1 108/ijrdm-08-2012-0084.

Brakus, J. J., Schmitt, B. H., \& Zarantonello, L. (2009). Brand experience: What is it? How is it measured? Does it affect loyalty? Journal of Marketing, 73(3), 52-68. Available at: https://doi.org/10.1509/jmkg.73.3.52.

Buil, I., De Chernatony, L., \& Martínez, E. (2013). Examining the role of advertising and sales promotions in brand equity creation. Journal of Business Research, 66(1), 115-122. Available at: https://doi.org/10.1016/j.jbusres.2011.07.030.

Chin, W. W., Marcolin, B. L., \& Newsted, P. R. (2003). A partial least squares latent variable modeling approach for measuring interaction effects: Results from a Monte Carlo simulation study and an electronic-mail emotion/adoption study. Information Systems Research, 14(2), 189-217. Available at: https://doi.org/10.1287/isre.14.2.189.16018.

Choi, K.-S., Cho, W.-H., Lee, S., Lee, H., \& Kim, C. (2004). The relationships among quality, value, satisfaction and behavioral intention in health care provider choice: A South Korean study. Journal of Business Research, 57(8), 913-921. Available at: https://doi.org/10.1016/s0148-2963(02)00293-x.

Davcik, N., da Silva, R. V., \& Hair, J. (2015). Towards a unified theory of brand equity: Conceptualizations, taxonomy and avenues for future research. Journal of Product and Brand Management, 24(1), 3-17. Available at: https://doi.org/10.1 108/jpbm01-2015-0797.

Farquhar, P. H. (1989). Managing brand equity. Marketing Research, 1(3), 24-33.

Fornell, C., \& Larcker, D. F. (1981). Evaluating structural equation models with unobservable variables and measurement error. Journal of Marketing Research, 18(1), 39-50. Available at: https://doi.org/10.1177/002224378101800104.

Frow, P., \& Payne, A. (2007). Towards the 'perfect'customer experience. Journal of Brand Management, 15(2), 89-101.

Gefen, D., \& Straub, D. (2005). A practical guide to factorial validity using PLS-Graph: Tutorial and annotated example. Communications of the Association for Information systems, $16(1), 5$.

Hansen, F., \& Christensen, L. B. (2003). Branding and advertising. Copenhagen: Business School Press DK.

Hekkert, P., \& Leder, H. (2008). Product aesthetics Product experience (pp. 259-285). San Diego: Elsevier.

Johansson, J. (2007). Working with events to build destination brand identity. Goeteborg University, Master Thesis.

Jung, H. S., Kim, K. H., \& Lee, C. H. (2014). Influences of perceived product innovation upon usage behavior for MMORPG: Product capability, technology capability, and user centered design. Journal of Business Research, 67(10), 2171-2178. Available at: https://doi.org/10.1016/j.jbusres.2014.04.027.

Kasper, H., Strepp, Y., \& Terblanche, N. (2005). An exploratory qualitative study of brand associations as a means for brand extensions: Part 1: Management. South African Journal of Economic and Management Sciences, 8(3), 272-286. Available at: https://doi.org/10.4102/sajems.v8i3.1205.

Keller, K. L. (1993). Conceptualizing, measuring, and managing customer-based brand equity. Journal of Marketing, 57(1), 1-22. Available at: https://doi.org/10.1177/002224299305700101.

Keller, K. L. (2007). Advertising and brand equity. Los Angeles: Sage Publications.

Kiska, J. (2002). Customer experience management. CMA Magazine, 76(7), 28-28.

Kotler, P., Keller, K. L., Ancarani, F., \& Costabile, M. (2014). Marketing management 14/e. London: Pearson.

Kumar, M., \& Noble, C. H. (2016). Beyond form and function: Why do consumers value product design? Journal of Business Research, 69(2), 613-620.

Lee, J.-S., \& Back, K.-J. (2010). Reexamination of attendee-based brand equity. Tourism Management, 31(3), 395-401. Available at: https://doi.org/10.1016/j.tourman.2009.04.006.

Lin, C.-H., Sher, P. J., \& Shih, H.-Y. (2005). Past progress and future directions in conceptualizing customer perceived value. International Journal of Service Industry Management, 16(4), 318-336. Available at: https://doi.org/10.1108/09564230510613988.

Luchs, M., \& Swan, K. S. (2011). Perspective: The emergence of product design as a field of marketing inquiry. Journal of Product Innovation Management, 28(3), 327-345. Available at: https://doi.org/10.1111/j.1540-5885.2011.00801.x.

Mahajan, A., Alloul, H., Collin, G., \& Marucco, J. (1994). 89 Y NMR probe of Zn induced local moments in YBa 2 (Cu 1-y Zn y) 3 O 6+ x. PhRvL, 72(19), 3100-3103. Available at: https://doi.org/10.1103/physrevlett.72.3100.

Manuel, M., Iglesias, C., Donnet, M., Leroy, F., Heckman, C., \& Zytnicki, D. (2009). Fast kinetics, high-frequency oscillations, and subprimary firing range in adult mouse spinal motoneurons. Journal of Neuroscience, 29(36), 11246-11256. Available at: https://doi.org/10.1523/jneurosci.3260-09.2009.

Marques, C., da Silva, R. V., Davcik, N. S., \& Faria, R. T. (2020). The role of brand equity in a new rebranding strategy of a private label brand. Journal of Business Research, 117, 497-507. Available at: https://doi.org/10.1016/j.jbusres.2020.06.022.

Journal of Contemporary Research in Business, Economics and Finance
ISSN: $2641-0265$
Vol. 2, No. 3, pp. $61-70,2020$
DOI: $10.33094 / 26410265.2020 .23 .61 .70$
C) 2020 by the authors; licensee Learning Gate


Mishra, A. (2016). Attribute-based design perceptions and consumer-brand relationship: Role of user expertise. Journal of Business Research, 69(12), 5983-5992. Available at: https://doi.org/10.1016/j.jbusres.2016.05.012.

Mitchell, A. A., \& Dacin, P. A. (1996). The assessment of alternative measures of consumer expertise. Journal of Consumer Research, 23(3), 219-239. Available at: https://doi.org/10.1086/209479.

Nelson, R. R. (1994). The co-evolution of technology, industrial structure, and supporting institutions. Industrial and corporate change, 3(1), 47-63.

Noble, C. H., \& Kumar, M. (2010). Exploring the appeal of product design: A grounded, value-based model of key design elements and relationships. Journal of Product Innovation Management, 27(5), 640-657. Available at: https://doi.org/10.1111/j.1540-5885.2010.00742.x.

Nunnally, J. C., \& Bernstein, I. H. (1994). Psychological theory. New York: McGraw-Hill.

Pappu, R., \& Quester, P. (2016). Brand innovativeness effects on perceived quality, satisfaction and loyalty Looking forward, looking back: Drawing on the past to shape the future of marketing (pp. 763-763): Springer.

Payne, A., Holt, S., \& Frow, P. (2000). Integrating employee, customer and shareholder value through an enterprise performance model: An opportunity for financial services. The International Journal of Bank Marketing, 18(6), 258-273. Available at: https://doi.org/10.1108/02652320010358689.

Petruzzellis, L., \& Somma, E. (2010). Bundling, Mass Customization andCompetition under Consumption Uncertainty (pp. 275294): World Scientific.

Prasad, K., \& Dev, C. S. (2000). Managing hotel brand equity: A customer-centric framework for assessing performance. The Cornell Hotel and Restaurant Administration Quarterly, 41(3), 22-24.

Sarstedt, M., Hair, J. F., Ringle, C. M., Thiele, K. O., \& Gudergan, S. P. (2016). Estimation issues with PLS and CBSEM: Where the bias lies! Journal of Business Research, 69(10), 3998-4010. Available at: https://doi.org/10.1016/j.jbusres.2016.06.007.

Schudson, M. (1984). Advertising, the uneasy persuasion: It's dubious impact on American Society. NY: Basic Book. Inc.

Severi, E., \& Ling, K. C. (2013). The mediating effects of brand association, brand loyalty, brand image and perceived quality on brand equity. Asian Social Science, 9(3), 125-137. Available at: https://doi.org/10.5539/ass.v9n3p 125.

Shariq, M. (2018). BRAND EQUITY DIMENSIONS-A LITERATURE REVIEW. International Research Journal of Management and Commerce, 5(3), 312.

Sharma, P., Davcik, N. S., \& Pillai, K. G. (2016). Product innovation as a mediator in the impact of R\&D expenditure and brand equity on marketing performance. Journal of Business Research, 69(12), 5662-5669. Available at: https://doi.org/10.1016/j.jbusres.2016.03.074.

Sweeney, J. C., \& Soutar, G. N. (2001). Consumer perceived value: The development of a multiple item scale. Journal of Retailing, 77(2), 203-220. Available at: https://doi.org/10.1016/s0022-4359(01)00041-0.

Teas, R. K., \& Agarwal, S. (2000). The effects of extrinsic product cues on consumers' perceptions of quality, sacrifice, and value. Journal of the Academy of Marketing Science, 28(2), 278-290. Available at: https://doi.org/10.1177/0092070300282008.

Wang, C.-L., Siu, N. Y., \& Hui, A. S. (2004). Consumer decision-making styles on domestic and imported brand clothing. European Journal of Marketing, 38(1/2), 239-252.

Yoo, B., Donthu, N., \& Lee, S. (2000). An examination of selected marketing mix elements and brand equity. Journal of the Academy of Marketing Science, 28(2), 195-211. Available at: https://doi.org/10.1177/0092070300282002.

Zeithaml, V. A. (1988). Consumer perceptions of price, quality, and value: A means-end model and synthesis of evidence. Journal of Marketing, 52(3), 2-22.

Zhang, J., Jiang, Y., Shabbir, R., \& Du, M. (2015). Building industrial brand equity by leveraging firm capabilities and co-creating value with customers. Industrial Marketing Management, 51, 47-58. Available at: https://doi.org/10.1016/j.indmarman.2015.05.016.

Journal of Contemporary Research in Business, Economics and Finance
ISSN: 2641-0265
Vol. 2, No. 3, pp. $61-70,2020$
DOI: $10.33094 / 26410265.2020 .23 .61 .70$
C) 2020 by the authors; licensee Learning Gate

